\title{
Ordinal Position
}

National Cancer Institute

\section{Source}

National Cancer Institute. Ordinal Position. NCI Thesaurus. Code C46126.

A number designating a place in an ordered sequence. 